International Research Journal of Management, IT \& Social Sciences
Available online at https://sloap.org/journals/index.php/irjmis/
Vol. 6 No. 3, May 2019, pages: 101 107
ISSN: 2395-7492
https://doi.org/10.21744/irjmis.v6n3.638

\title{
Effect of Budget Participation towards Regional Government Managerial Performance
}

\author{
Fransiscus De Romario ${ }^{a}$ \\ I Gusti Ayu Made Asri Dwija Putri ${ }^{\text {b }}$ \\ I Dewa Nyoman Badera ${ }^{c}$ \\ I Nyoman Wijana Asmara Putra ${ }^{d}$
}

Article history:

Received: 27 December 2018

Accepted: 31 March 2019

Published: 31 May 2019

\section{Keywords:}

budget participation;

leadership style;

managerial performance;

organizational commitment;

organizational culture;

\begin{abstract}
This research was intended at examining the effect of budget participation towards managerial performance with organizational commitment, jobrelevant information, organizational culture, and leadership style as moderating variables on local government in Sikka Regency, NTT. The questionnaire survey method was distributed to local government structural officials. The sampling technique was purposive sampling method. The data analysis technique used moderated regression analysis method. The results of the study showed: 1) budget participation has a positive effect on managerial performance, 2) organizational commitment was not able to moderate the effect of budget participation on managerial performance, 3) job-relevant information was able to act as a moderator that strengthens the effect of budget participation on managerial performance, 4) organizational culture was not able to moderate the effect of budget participation on managerial performance, 5) the leadership style was not able to moderate the effect of budget participation on managerial performance.
\end{abstract}

2395-7492@ Copyright 2019. The Author. This is an open-access article under the CC BY-SA license (https://creativecommons.org/licenses/by-sa/4.0/) All rights reserved.

Author correspondence:

Name of Author,

Faculty of Economics and Business, Universitas Udayana, Denpasar, Indonesia

Jl. Raya Kampus UNUD, Kampus Bukit Jimbaran, Badung, Bali 80361

Email address: ryoilenk00@gmail.com

\section{Introduction}

Participation in budgeting is an effective approach to increasing managerial motivation. Govindarajan (2010), stated that the participation shows the extent to which employees participate in budgeting as an accountability center that they lead. Regarding budget participation, it has a positive effect on its implementation. Due to all employees will

\footnotetext{
${ }^{a}$ Faculty of Economic and Business, Universitas Udayana, Denpasar, Indonesia

${ }^{\mathrm{b}}$ Faculty of Economic and Business, Universitas Udayana, Denpasar, Indonesia

${ }^{\mathrm{c}}$ Faculty of Economic and Business, Universitas Udayana, Denpasar, Indonesia

${ }^{\mathrm{d}}$ Faculty of Economic and Business, Universitas Udayana, Denpasar, Indonesia
} 
know the purpose to be achieved. Therefore, the employees will also better understand the problems that might arise during budget implementation.

Budget participation is also ways to create a good management control system. Therefore, the relevant institutional objectives are expected to be achieved. Regional apparatus in regional governments involved in the local governments budgeting process are given the opportunity to take part in decision making through budget planning. This is very important due to the regional government apparatus will feel more productive and satisfied with their work. Allowing for feelings emergence on the achievement that will improve their performance.

The phenomenon occurred in local governments related to the budget is an interesting matter to be further studied. In fact, the deviations are discovered by the audit board report. It is related to the alleged corruption committed by the regional apparatus in Sikka Regency government. This is thought to cause state losses in it. Unlike the corruption case the construction of alok market in Sikka Regency. It was conducted by the regional apparatus.

The problem in this study can be formulated regarded effect on managerial performance. 1) What budget participation affect? 2). What the organizational commitment able to moderate the effect of budget participation? 3) What the job-relevant information able to moderate the effect of budget participation? 4) What the organizational culture able to moderate the effect of budget participation? 5) What the leadership style able to moderate the effect of budget participation?

\section{Literature Review and Research Hypothesis}

Locke (1968), was initially put forward the goal setting theory. It showed a correlation between the goal and performance towards the task. Agency theory describes the agency relationship between the agent and the principal. Contingency theory discusses the leadership style depending on the organization situation.

The budget has an important role in managerial planning and control instrument. The function is as a control instrument, budget is used as a system to measure the organizational performance. Good performance can earn output that matches with the input. Therefore, the budget is controlling instrument controls, the use of resources owned to achieve optimal results. Ferdiani \& Rohman (2012), participation in budgeting is an activity to develop a budget that involves each level of the employees. It is considered a managerial approach that can improve organizational performance. Budiman et al., (2014), based on the above explanation, the first hypothesis in this study is as follows. H1: There is a positive effect of budget participation.

Sradjito \& Muthaher (2012), organizational commitment is an encouragement from the individual to do something in order to support the successful organization in accordance with the interests objectives and prioritize of the organization compared to their own interests. The encouragement exists in each individual can affect the successful organization, if the individual participates in budgeting will also improve managerial performance

Regarding the existence of high organizational commitment, it will also indirectly improve high performance. Sari et al., (2014), the higher organizational commitment in each individual or local government apparatus will improve good performance. Based on the above explanation, the second hypothesis in this study is as follows.

$\mathrm{H} 2$ : Organizational commitment strengthens the effect of budget participation.

Job relevant information is information that facilitates the decision-making related to tasks. Kren (2013) and Sari \& Dwirandra (2019), the availability of information related to the task will increase the actions planned choice to achieve the goal. It shows the information role in facilitating the decision-making on the office-related. Budget participation enables the transfer of adequate information, therefore, a better level of relevant knowledge understanding for the task will be obtained. Indarto \& Ayu (2011), relevant information will help top managers understand and choose good actions in achieving goals. Based on the above explanation, the third hypothesis in this study is as follows.

H3: Job relevant information strengthens the effect of budget participation on managerial performance

Organizational culture is the score of the beliefs held by organization members as outlined in the behavior norms for individuals or groups of organizations addressed the work (Hofstede at al., 1990; Yunita \& Saputra, 2019); Hidayat \& Budiatma (2018). Holmes \& Marsden (1996), stated that organizational culture has an effect on behavior, workings and managers motivation, and subordinates to achieve organizational performance. Based on the above explanation, the fourth hypothesis in this study is as follows.

H4: Organizational culture strengthens the influence of budget participation.

According to Decoster \& Fertakis (1968) and Mora \& Triana (2018), the leadership style can be divided into two dimensions. First, initiating structure shows the leaders behavior related to second job performance. Consideration leadership style shows close relationships, trust each other, and care for each other between leaders and subordinates. The leadership style type superiors in the agency will greatly affect their subordinates. The budget participation 
leadership styles can effect subordinate's contributions to conveying their opinions/participation. It will also have an effect on the performance of employees or organizations. Good leadership style in budget participation can improve managerial performance. Based on the above explanation, the fifth hypothesis in this study is as follows.

H5: Leadership style strengthens the effect of budget participation.

\section{Materials and Methods}

The study location was conducted in Sikka Regency, NTT. It has 30 regional organizations. The research respondents were structural officials of audit board report in Sikka Regency, NTT involved in budgeting. The population was 30 regional organizations in Sikka Regency, NTT. The respondents sampling was done using purposive sampling. The first criterion is structural officials involved in the budgeting process. The second criterion is having tenure and having been involved in preparing a budget of at least one year. The structural officials involved were officials at the head of the service level, head of the bureau, and section head.

The questionnaire was applied as the technique of collecting the data. The data quality test used, namely the validity test and reliability test. Classic assumption test used was the normality test, multicollinearity test, and heteroscedasticity test. The hypothetical test used was the simple linear regression analysis and the moderated regression model test.

\section{Results and Discussions}

\section{Data Quality Test}

The results of the validity test show that all variable indicators have a $\mathrm{R}_{\text {count }}$ value higher than $\mathrm{R}_{\text {table }}(0$,). Therefore, it can be concluded all indicators meet the data validity requirements. Reliability test shows that the Cronbach alpha value is $>0.6$. Indicating the data used is reliable.

\section{Classic Assumption Test}

Normality test performed shows that Asymp. Sig. value is 0.095 . The results of the normality test performed the data is normally distributed. It is indicated by a significance value is $0.095>0.05$. The multicollinearity test conducted shows the tolerance value for all variables higher about 0.1 . Therefore, VIF is lower than 10 . The result shows all independent variables in the two equations do not have a linear relationship between independent variables. It means both equations have met the multicollinearity assumptions. Heteroscedasticity test shows the significance value is higher than 0.05 . Therefore, it can be stated that there is no heteroscedasticity.

\section{Hypothesis test}

Simple linear regression analysis is used to determine the effect of one independent variable on the dependent variable.

Table 1

Simple linear regression test results

\begin{tabular}{lllllll}
\hline & \multicolumn{5}{c}{ Unstandardized Coefficients } & \multicolumn{2}{c}{$\begin{array}{c}\text { Standardized } \\
\text { Coefficients }\end{array}$} & & Sig. \\
\cline { 3 - 5 } Model & & B & Std. Error & Beta & t & S \\
\cline { 3 - 6 } 1 & $($ Constant $)$ & 22,922 & 3,841 & & 5,968 &, 000 \\
& $\mathrm{X}$ &, 938 &, 088 &, 703 & 10,635 &, 000 \\
\hline
\end{tabular}

Source: processed data, 2018

Table 1 present the significance $\mathrm{t}$-value is $0,000<0.05$. Therefore, $\mathrm{H} 0$ is rejected. It defines there is a significant effect of budget participation variable $(\mathrm{X})$ on managerial performance variables $(\mathrm{Y})$.

Romario, F. D., Putri, I. G. A. M. A. D., Badera, I. D. N., \& Putra, I. N. W. A. (2019). Effect of budget participation towards regional government managerial performance. International Research Journal of Management, IT and Social Sciences, 6(3), 101-107. https://doi.org/10.21744/irjmis.v6n3.638 
Moderated Regression Model Test

The instrument test used in the current study is moderated regression analysis (MRA). The test is useful to determine the effect of moderated variables in strengthening or weakening the effect of independent variables on the dependent variable.

Table 2

Moderated regression test results

\begin{tabular}{|c|c|c|c|c|c|c|}
\hline \multirow[b]{2}{*}{ Model } & \multirow[b]{3}{*}{ (Constant) } & \multicolumn{4}{|c|}{$\begin{array}{l}\text { Standardized } \\
\text { Coefficients }\end{array}$} & \multirow[b]{2}{*}{ Sig. } \\
\hline & & $\mathrm{B}$ & Std. Error & Beta & $\mathrm{t}$ & \\
\hline \multirow[t]{10}{*}{1} & & 20,986 & 5,298 & & 3,961 &, 000 \\
\hline & $\mathrm{X}$ &,- 090 & , 146 &,- 067 &,- 612 & ,542 \\
\hline & M1 &, 547 & 241 & 439 & 2,271 & 025 \\
\hline & M2 &,- 681 & 365 &,- 381 & $-1,868$ & 065 \\
\hline & M3 &, 253 & , 177 & ,261 & 1,427 &, 156 \\
\hline & M4 & 475 & ,204 &, 567 & 2,335 &, 021 \\
\hline & X_M1 &,- 004 & 006 &,- 234 &,- 730 & 467 \\
\hline & X_M2 & ,020 & 008 &, 740 & 2,403 & 018 \\
\hline & X_M3 & ,002 & ,004 & ,096 & ,358 &, 721 \\
\hline & X_M4 &,- 006 & ,005 &,- 419 & $-1,257$ & ,211 \\
\hline
\end{tabular}

Source: processed data, 2018

Table 2 shows the significance $t$-value for job-relevant information moderated variable is $(M 2)<0.05$. Therefore, $\mathrm{H} 0$ is rejected. It defines there is a significant effect. The significance $t$-value organizational commitment variable is (M1), organizational culture variable (M3), and leadership style variable (M4)>0.05. Thus, H0 is accepted. It defines there is no significant effect.

\section{Discussion}

H1: There is a positive effect of budget participation on managerial performance.

Simple linear regression test results is significance $0,000<0.05$. Therefore, $\mathrm{H} 0$ is rejected. It defines significantly effect of budget participation variable $(\mathrm{X})$ on managerial performance variable $(\mathrm{Y})$. It means the first hypothesis is acceptable. The first hypothesis proposed in the present study is budget participation mastering good effect regarded the managerial performance. The involvement of individuals or government officials related to their participation in budgeting, it will encourage employees or government officials to be responsible for their work. Thus, they will improve their performance.

$\mathrm{H} 2$ : Organizational commitment strengthens the effect of budget participation on managerial performance

The statistical test result of moderated regression is conducted. It is known organizational commitment has a nonsignificant value is 0.467 . Thus, organizational commitment variable cannot moderate effect on budget participation variable toward managerial performance for the local governments. It means the second hypothesis is not acceptable. It is due to the lack of local government employees commitment to the organization they work in.

H3: Job relevant information strengthens the effect of budget participation on managerial performance

The statistical test result of moderated regression is conducted. It is known job-relevant information has significant value is 0.018 . Therefore, job-relevant information variable is a moderated variable that strengthens budget participation correlation variable to managerial performance for the local government. It means the third hypothesis is acceptable. Job relevant information improves performance by giving a more accurate estimate regarded environment. Thus, the best effective action series can be selected. The information helps managers to improve their performance with better information. 
H4: Organizational culture strengthens the effect of budget participation on managerial performance.

The statistical test results of moderated regression is conducted. It is known organizational culture has a nonsignificant value is 0.721 . therefore, organizational culture variable cannot moderate the effect of budget participation variable on managerial performance for the local governments. It means the fourth hypothesis is not acceptable.

H5: Leadership Style strengthens the influence of budgetary participation on managerial performance.

The statistical test result of moderated regression is conducted. It is known leadership style has a non-significant value is 0.211 . therefore, it can be concluded leadership style variable cannot moderate variable effect on budget participation variable toward managerial performance for the local government. It means the fifth hypothesis is not acceptable. The leadership style is not able to moderate the effect of budget participation on managerial performance probably due to the leaders who tend to give less opportunity to provide sharing their opinions on the participatory on the budgeting process.

\section{Conclusion}

The five conclusions can be drawn in the current research. 1) There is a positive influence of budget participation on managerial performance. 2) Organizational commitment is not able to moderate the effect of budget participation on government managerial performance. 3) Job relevant information is able to act as a moderator that strengthens the effect of budget participation on the managerial performance of regional governments. 4) Organizational culture is not able to moderate the effect of budget participation on government managerial performance. 5) Leadership style is not able to moderate the effect of budget participation on managerial performance for the local governments.

\section{Suggestion}

There are three suggestions. 1) The further studies should be able to add variables that the researcher did not input on this study. 2) Future research can do research with far more respondents. 3) The subsequent research should be supplemented interviewing and substitution for research sampling techniques, as well as, the change on alternative answers selection to the questionnaire. Therefore, it can explore all the terms become objectives.

Conflict of interest statement and funding sources

The authors declared that they have no competing interest. The study was financed by personal funding.

Statement of authorship

The authors have a responsibility for the conception and design of the study. The authors have approved the final article.

\section{Acknowledgments}

The authors would like to acknowledge the editor of IRJMIS for their valuable time, support and advice in completing the current article.

Romario, F. D., Putri, I. G. A. M. A. D., Badera, I. D. N., \& Putra, I. N. W. A. (2019). Effect of budget participation towards regional government managerial performance. International Research Journal of Management, IT and Social Sciences, 6(3), 101-107. https://doi.org/10.21744/irjmis.v6n3.638 


\section{References}

Budiman, C. A., Sari, R. N., \& Ratnawati, V. (2014). Pengaruh Partisipasi Penyusunan Anggaran Terhadap Kinerja Manajerial Dengan Gaya Kepemimpinan, Motivasi Dan Job Relevant Information Sebagai Variabel Intervening. Sorot, 9(1), 86-103.

DeCoster, D. T., \& Fertakis, J. P. (1968). Budget-induced pressure and its relationship to supervisory behavior. Journal of Accounting Research, 237-246. https://doi.org/1010.2307/2490238

Ferdiani, D., \& Rohman, A. (2012). Pengaruh partisipasi anggaran terhadap kinerja manajerial pegawai sekretariat daerah provinsi jawa tengah: komitmen organisasi dan persepsi inovasi sebagai variabel intervening (Doctoral dissertation, Fakultas Ekonomika dan Bisnis).

Govindarajan, V., \& Trimble, C. (2010). The other side of innovation: Solving the execution challenge. Harvard Business Press.

Hidayat, R., \& Budiatma, J. (2018). Education and job training on employee performance. International Journal of Social Sciences and Humanities, 2(1), 171-181. https://doi.org/10.29332/ijssh.v2n1.140

Hofstede, G. (2011). Dimensionalizing cultures: The Hofstede model in context. Online readings in psychology and culture, 2(1), 8. https://doi.org/10.9707/2307-0919.1014

Holmes, S., \& Marsden, S. (1996). An exploration of the espoused organizational cultures of public accounting firms. Accounting Horizons, 10(3), 26.

Indarto, S. L., \& Ayu, S. D. (2011). Pengaruh Partisipasi dalam Penyusunan Anggaran terhadap Kinerja Manajerial Perusahaan melalui Kecukupan Anggaran, Komitmen Organisasi, Komitmen Tujuan Anggaran, dan Job Relevant Information (JRI). Seri Kajian Ilmiah, 14(1), 1-22.

Kren, L. (1992). Budgetary participation and managerial performance: The impact of information and environmental volatility. Accounting Review, 511-526.

Mora, M. L. C., \& Triana, M. S. F. (2018). The Management of Process of the Budget Area. International Research Journal of Management, IT and Social Sciences, 5(2), 104-112.

Sardjito, B., \& Muthaher, O. (2007). Pengaruh Partisipasi Penyusunan Anggaran Terhadap Kinerja Aparat Pemerintah Daerah. Budaya Organisasi dan Komitmen Organisasi Sebagai Variabel Moderating, SNA X, Makassar.

Sari, I. G. A. D. I., \& Dwirandra, A. (2019). The ability of organization commitment and moderate worked motivation by the effect of budget goal clarity in budgetary inaccuracy. International Research Journal of Management, IT and Social Sciences, 6(3), 11-17. https://doi.org/10.21744/irjmis.v6n3.622

Sari, L. P. D. M., Adiputra, I. M. P., SE, S., Si, M., Yuniarta, G. A., \& AK, S. (2014). Pengaruh Partisipasi Penyusunan Anggaran Terhadap Kinerja Aparat Pemerintah Daerah Dengan Kepuasan Kerja Dan Komitmen Organisasi Sebagai Variabel Moderating (Studi Empiris Pada Pemerintah Daerah Kabupaten Badung). JIMAT (Jurnal Ilmiah Mahasiswa Akuntansi) Undiksha, 2(1).

Yunita, P. I., \& Saputra, I. G. N. W. H. (2019). Millennial generation in accepting mutations: Impact on work stress and employee performance. International Journal of Social Sciences and Humanities, 3(1), 102-114. https://doi.org/10.29332/ijssh.v3n1.268 


\section{Biography of Authors}

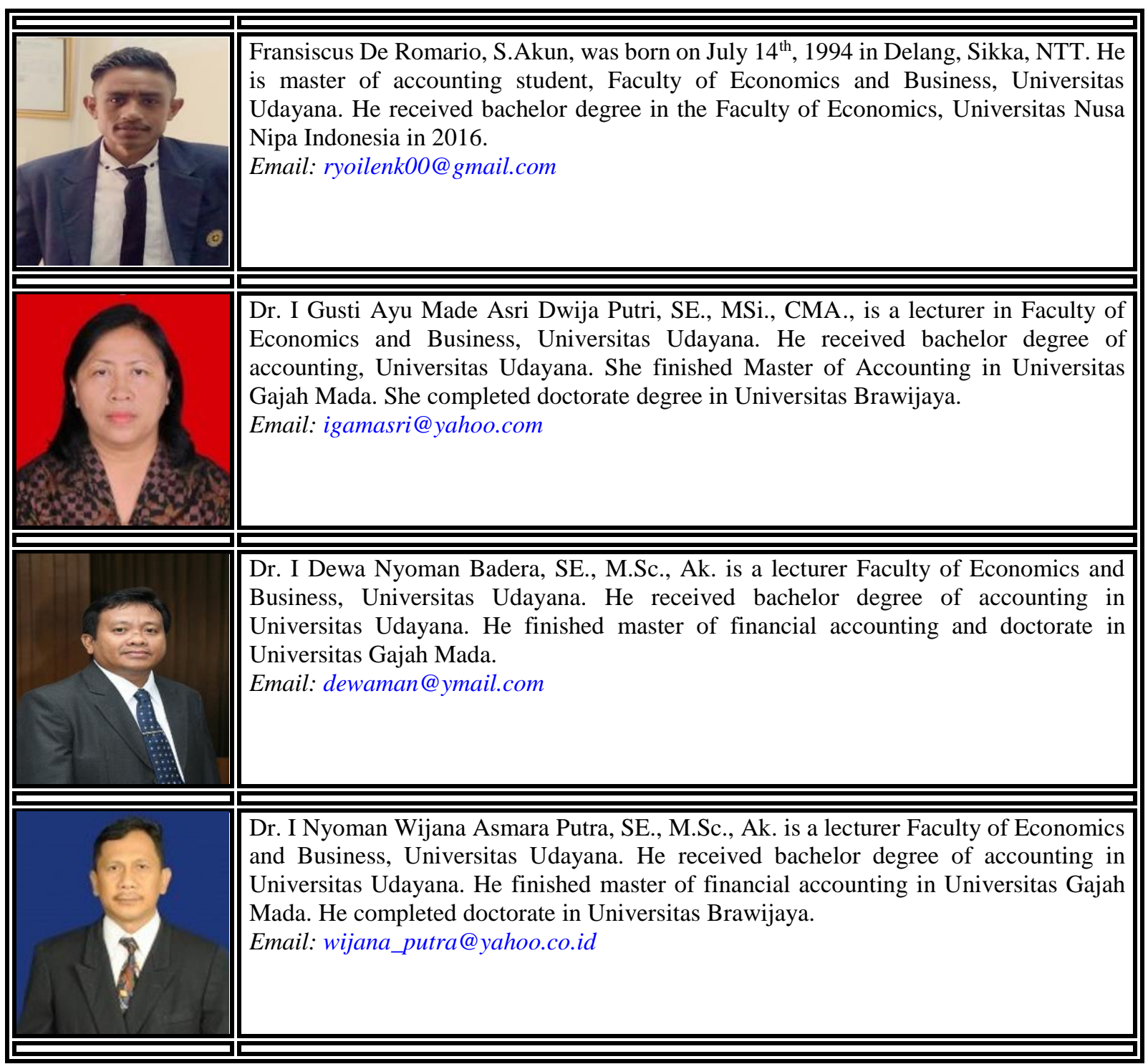

Romario, F. D., Putri, I. G. A. M. A. D., Badera, I. D. N., \& Putra, I. N. W. A. (2019). Effect of budget participation towards regional government managerial performance. International Research Journal of Management, IT and Social Sciences, 6(3), 101-107. https://doi.org/10.21744/irjmis.v6n3.638 